\section{Reedição de fontes para quê? Algumas reflexões em torno de um roteiro de viagem pela Amazónia luso-brasileira}

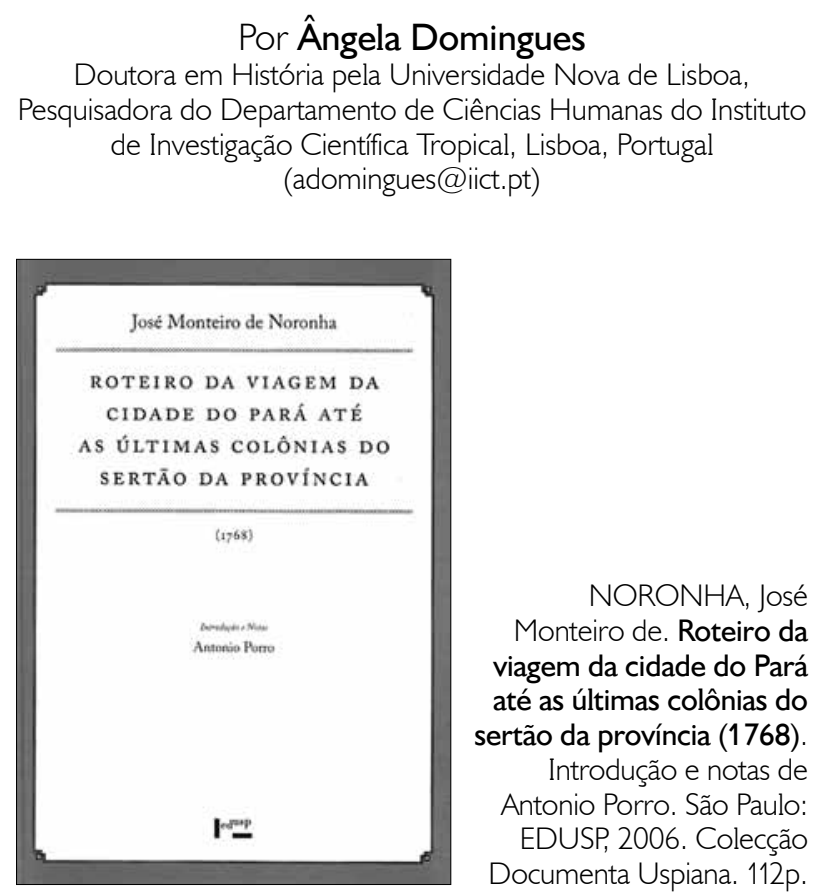

Em boa hora, a Colecção Documenta Uspiana disponibiliza mais um documento que, consideram os organizadores dessa colecção, é de relevância para a compreensão da História e da Cultura do Brasil. Creio que desvalorizar a necessidade de publicação deste "Roteiro da cidade do Pará até as últimas colónias do sertão da província” por ter já sido publicado quatro vezes (a última na Revista do Instituto Histórico e Geográfico Brasileiro, em 1989) é algo de imponderado: um documento com esta significância, anotado e precedido de uma introdução com a qualidade a que um especialista como Antonio Porro nos habituou, justifica plenamente a pertinência de uma edição autónoma (tenha-se presente, por exemplo, o trabalho de selecção, introdução e anotação desenvolvido por este estudioso em "As crónicas do rio Amazonas", de 1992).

O "Roteiro..." filia-se, a meu ver, a uma característica da cultura científica portuguesa (e ibérica) setecentista: em uma altura em que a ciência e as práticas e técnicas científicas evoluíam céleres, também os registos científicos se alteravam e aperfeiçoavam, embora (ao contrário do que acontecia em outros países europeus) permanecessem manuscritos. De facto, ao longo do século XVIII, não apenas a Amazónia, como o Brasil (e a América do Sul, em geral), foram objecto de atenção de cientistas que viajaram e registaram esse imenso território de acordo com os critérios científicos mais actualizados para o seu período. Contudo, os registos textuais, iconográficos e cartográficos produzidos ficariam na sua maioria inéditos, como ocorreu com este "Roteiro...".

Como o seu nome indica, o "Roteiro..." foi elaborado pelo autor com o propósito de guiar os viajantes pelos rios do sertão amazónico, as capitanias do Pará e Rio Negro compreendidas, e assim fornecer-lhes informações gerais, úteis e concisas, mas importantes, práticas e precisas sobre a constituição do labirinto hidrográfico amazónico, tipos de ocupação e locais de povoamento, ligações entre rios, furos e igarapés, comunicações com outras regiões e países, rotas a seguir para uma melhor brevidade e segurança de viagem, dificuldades e perigos de navegação e formas de os contornar. Esclarecimentos de geografia natural cruzam-se com dados de geografia humana, antropologia, política, economia, no sentido de elucidar o viajante sobre quais os povos que habitavam a região, - e características identificadoras de cada grupo, grau de tolerância/proximidade com os colonos, língua, prática de antropofagia, endofagia ou circuncisão, descrição de armas, utilização de venenos -; bem como as principais produções naturais passíveis de exploração económica, ou seja e parafraseando Jack Greene, "os atributos físicos da colónia".

A preocupação com a quantificação está sempre presente no texto de José Monteiro de Noronha, com o autor a registar as latitudes (mas, curiosamente, não as longitudes, com uma única excepção) para os locais geográfica e politicamente mais emblemáticos (por exemplo: Belém, Macapá, Cabo Norte, rio Cassiquiari), ou as distâncias que separam uma povoação, um lugar, 
um curso de água, do que lhe está imediatamente mais próximo, avaliadas em dias de navegação ou em léguas.

Homem do seu tempo, o funcionário judicial tornado vigário-geral em 1760 (cf. "Introdução", p. 12-13) revela interesse pela produção científica e intelectual que se escreveu sobre ou que, de algum modo, pudesse estar relacionada com o seu "espaço de pertença": leu atentamente Charles Marie de La Condamine (que desceu o rio Amazonas em 1743), o conde de Buffon, Vicente Maria Coronelli e o naturalista João da Silva Feijó, cujos escritos utiliza no "Roteiro...". Todavia, tendo quase "orgulho" de um conhecimento feito de prática e experiência directa, não hesita em corrigir ou tornar mais precisas as opiniões desses autores conceituados, cujos escritos parece considerar reflectirem um saber superficial ou apressadamente apreendido, nem, tão-pouco, em valorizar o saber índio como uma fonte tão digna de registo (e, logo, de credibilidade) como outras (v. parágrafo 95, p. 47). Será que a "informação superior" de Monteiro de Noronha reside, precisamente, na valorização desse saber prático?

As potencialidades dessa fonte ultrapassam, claramente, os propósitos imediatos com que foi criada, tornando-se a sua leitura tão válida para estudiosos do século $X X I$ como, em tempos, terá sido para os viajantes do sertão paraense. Uma das suas utilidades foi já apontada por Walter Cardoso (s.d., p. 83), quando, em comentário recente, referiu que esse texto escrito por um "não-cientista" e com propósitos "não-científicos" podia ser utilizado como uma ferramenta válida para o ensino da História da Ciência.

De igual modo, creio, a historiadores e antropólogos ficam abertas várias possibilidades de utilização desse texto: por exemplo, como contribuição para o estudo das deslocações, do desalojamento e da extinção de etnias ameríndias em território amazónico, quando se mencionam etnias que já tinham habitado locais agora desabitados, quando se refere à realização de expedições punitivas, ao mencionar-se a transferência de "aldeias índias" para lugares e vilas, bem como a junção de diferentes etnias em um povoado colonial. Assim, parece-me que o olhar/roteiro de Monteiro de Noronha, apesar de conciso, disciplinado e, talvez, "asséptico" (?), possa ser perspectivado pelos actuais leitores como um registo contribuidor para o conhecimento das consequências que a presença e actuação de portugueses tiveram em parte substantiva da bacia hidrográfica amazónica, no sentido de reorganizar o espaço de acordo com as normas e padrões europeus.

A edição do "Roteiro..." é acompanhada da "Collecção de prospectos das aldeias e lugares mais notáveis que se acham em o Mapa que tiraram os Engenheiros da expedição principiando da cidade do Pará the aaldeia de Mariuá no Rio-negro... por ordem do Illustrissimo e Excellentissimo Senhor Francisco Xavier de Mendonça Furtado", executados por João André Schwebel em 1756. A ideia é interessante e aponta para a complementaridade existente entre texto e imagem. Pena é que a vontade de reforçar o interesse das palavras do "Roteiro..." com o apelo da iconografia da "Collecção..." não tenha sido conseguida de modo satisfatório, devido à má qualidade de reprodução e à publicação truncada das representações.

\section{REFERÊNCIAS}

CARDOSO, Walter. Ensino da História da Ciência através da interpretação de textos. Disponível em http://www.mast.br/ arquivos_sbhc/280.pdf. Acessado em 03/03/2009.

NORONHA, José Monteiro de. Roteiro da viagem da cidade do Pará até as últimas colônias do sertão da província (1768). Revista do Instituto Histórico e Geográfico Brasileiro, v. 150, n. 364, p. 475-513, jul.-set. 1989.

PORRO, Antonio. As crônicas do rio Amazonas. Notas etno-históricas sobre as antigas populações indígenas da Amazónia. Petrópolis, Rio de Janeiro: Editora Vozes, 1992. 